\title{
Budget axe threatens social science directorate at NSF
}

\begin{abstract}
Washington. The social, behavioural and economic sciences (SBES) directorate of the US National Science Foundation (NSF) is widely expected to be eliminated after a powerful congressional committee instructed the agency to cut the number of directorates from seven to six.

The social sciences will still receive support from the NSF. Robert Walker (Republican, Pennsylvania), chairman of the House of Representatives Science Committee, said that the two-year NSF authorization bill that his committee passed last week "did not zero out" such funding, which came to a total of $\$ 114$ million this year.

But the order to shut a directorate will probably be applied to SBES, which is newer and far smaller than NSF's other six directorates. If that happens, the social sciences will have to compete with the 'hard' sciences for funds within other directorates, officials say - and social sciences are unlikely to do well in such a competition.
\end{abstract}

The directorate provides 60 per cent of all US federal support for research in the social sciences in US universities. Discussing social science research at a press conference in May, Walker said that the NSF had "wandered into these areas in recent years" when doing so was "politically correct". He added that NSF should, in his view, concentrate on the physical sciences.

The anticipated move to close the directorate is, therefore, something of a retreat by Walker, who had earlier hinted that the social sciences might lose their funding altogether. Neal Lane, director of the NSF, and Kumar Patel, president of the American Physical Society, were among those who had pressed Walker not to go that far.

NSF will spend $\$ 3.264$ billion this year, and the bill passed by Walker's committee

\section{Mouse gene repository}

Munich. The European Commission is expected to approve next week funding for a new European mouse gene repository, to be based at Monterotondo, near Rome.

A recommendation for such funding was approved last week by the consultative committee for the commission's biotechnology programme. The repository will contain a collection of mutant mouse strains to be made available on request to research scientists, and will complement a major genetics centre being established at Monterotondo (see Nature 374, 296; 1995).

A grant of ECU6 million (US\$4.6 million) from the commission over four years will also pay for the development of a supporting laboratory for the repository at Orléans in France.

A. A. last week gives it $\$ 3.126$ billion in the 1996 financial year, which starts in October, and $\$ 3.171$ billion in 1997 . Most of the reduction, however, will fall on infrastructure funds; the amount of money for research grants would slip only slightly, from $\$ 2.28$ billion this year to $\$ 2.226$ billion in 1996 , before recovering to $\$ 2.28$ billion in 1997 .

Congress's budget process still has three months to run. But these NSF figures will not change much, as the House appropriations committees are likely to accept them, and the Senate's own proposals are broadly similar (see Nature 375, 168; 1995).

The figures mean that the agency, which funds most non-biomedical university research in the United States, is having a bad year by its own high standards, seeing its budget cut for the first time since 1986. But it is still doing far better than other research agencies, such as the Department of Energy and the National Aeronautical and Space Administration.

Warning voices such as those of George Brown, the top Democrat on the Science

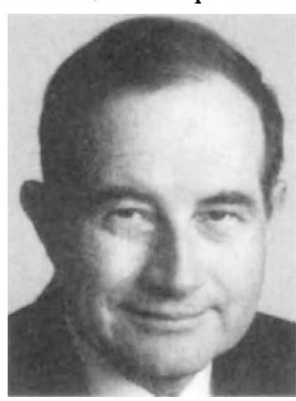

Lane: advised against eliminating funding.

committee, and the American Association for the Advancement of Science, point out that the NSF faces real cuts of 20 per cent between now and the year 2002 . But these are hypothetical projections built upon a number of political and economic imponderables, and should not be confused with the cuts of one third - or more - which threaten energy research programmes, for example, next year.

Walker's NSF authorization bill also instructs the NSF to block all grants to institutions that receive 'earmarked' funds from congressional committees for projects that have not been peer-reviewed. But NSF officials fear that this will require them to decide what is an earmark - angering universities and congressmen in the process.

Until a single NSF authorization bill is agreed by both House and Senate and passed into law, the agency has some discretion in how it complies with the provisions in the Walker bill. It will probably eliminate a directorate, for example, because it can keep Walker happy by doing so, without alienating any other powerful interests in Congress.

By contrast, the block on grants to certain congressmen's pet institutions would clearly alienate such interests, and the NSF is widely expected to ignore it. Colin Macilwain

\section{German council under fire over 'political' influence on decisions}

Bonn. The Wissenschaftsrat, the science council responsible for assessing the work of research establishments in Germany, is itself to be evaluated. This follows a rare attack on its integrity in which the powerful state of Bavaria is claiming that the council has allowed itself to be influenced by the interests of federal politicians.

In response, officials of the Wissenschaftsrat claim Bavaria's accusations are based on self-interest. The state has been angered by a recent decision of the federal government to drop its full backing for the Wissenschaftsrat's proposals on university building and equipment, the costs of which are shared equally between the federal and Länder governments. This threatens Bavaria's ambitious university expansion plans.

This year, the federal government agreed to pay only DM1.8 million (US $\$ 1.3$ million) of its share, even though the Wissenschaftsrat had said that it should contribute DM2.3 million. In response, Bavaria said it wants to abandon the 25-year-old law on cost-splitting (see Nature 373, 95; 1995).

But its proposal received little support, as it would greatly disadvantage poorer Länder. As a result, Bavaria is now turning its attention to the science council's system of decision-making.

At the end of last month a meeting of the Länder prime ministers was asked to consider a proposal from Bavaria - which had already won the support of the Länder finance ministers - to limit the council's financing to two rather than five years while a review of its activities is carried out.

The prime ministers rejected Bavaria's proposal and renewed the Wissenschaftsrat's funding for a further five years. But they also agreed to a review of the council's activities in connection with university buildings and equipment.

A spokeswoman for the Bavarian research ministry says that Hans Zehetmair, the minister, suspects that the Wissenschaftsrat, which is supposed to make independent assessments of the needs of universities, has been influenced by pressures on the federal budget to limit its recommendations.

Zehetmair adds that the Wissenschaftsrat was due for a review, and that the university building issue provided an opportunity for it. But officials within the council believe his motive is to influence the debate on whether its formula for financing university building should be changed.

The organization of the review remains unclear. But research ministers will each nominate experts to the review panel immediately raising questions about its objectivity, says Winfried Benz, general secretary of the council.

Alison Abbott 